Preliminary communication

https://doi.org/10.32903/zs.66.1.4

UDK 004.738.5-055.52

\title{
BENEFITS AND DANGERS OF THE INTERNET FROM THE PERSPECTIVE OF PARENTS OF PRIMARY SCHOOL STUDENTS
}

\author{
Dr Tena Velki, associate professor \\ Faculty of Education, Croatia \\ Marlies Ivanković, Master of Primary Education
}

\begin{abstract}
The aim of this study was to examine parents' perceptions of the online benefits and dangers that their children encounter. Ninety-six parents participated in the study $(82.3 \%$ mothers and $17.7 \%$ fathers). Participants, parents of children attending primary school, filled out a questionnaire consisting of sociodemographic questions and a scale of attitudes about the benefits and dangers of electronic media (computers, the Internet and mobile phones). The results of the research showed that the frequency of the Internet use is related to the parents' perception of the benefits and dangers of the Internet. It was found that the more often parents use the internet, the less danger they perceive, and more benefits, and vice versa, the less often they use the Internet, they perceive more dangers and fewer benefits. At the same time, the results showed that the level of parental education is not significantly related to their perception of the benefits or dangers that their children encounter on the Internet. By increasing awareness of this issue and examining the actual state, teachers can specifically educate children and also parents about the safe use of the Internet.
\end{abstract}

Keywords: benefits, dangers, the Internet, parental perception

\section{INTRODUCTION}

Digital revolution with its fast expansion has changed not just the way we communicate, learn and have fun, but also the way we behave as individuals and within the group. The Internet has had the greatest influence on adolescents and children (Young and Nabuco de Abreu, 2017). Ružić (2011) states that the Internet has made people's lives easier, but that at the same time we have become much more exposed to various dangers lurking on the Internet.

Many of us still do not understand the potential dangers of using the Internet, from false identities with other people's profiles, false promises offering or even seeking financial and other assistance, to various forms of abuse that leave lasting psychological consequences on the user (Velki and Šolić, 2019).

The development of electronic media, their interactivity and greater opportunities for communication, along with many advantages and an interesting way of learning, represent a very big risk for everyone, but especially children and young people. Children and young people today live significantly differently than their parents used to and know much more about the electronic media, making the parental role even more complex. The media today, with an emphasis on the growing importance and presence of electronic media in the lives of children and youth, are becoming educators of new generations, given that children today spend more time in the company of various media than in school (Robotić, 2015). 
The media are neither harmful nor useful, and they can be both. Although the public most often deals with the dangerous and harmful side of the media, excessive violence, pornography, stereotypes, and sensationalism, they can also be a useful source of entertainment and information. Both ways influence socialization and the formation of the identities of children and adults, as well as national identities (Zgrabljić Rotar, 2005).

\section{THE INTERNET FROM PARENTS' PERSPECTIVE}

Mikić and Rukavina (2006) emphasize that children need to be educated to use the media and that parents have a great responsibility in this process. In the United Kingdom, a survey of children's media literacy is conducted every year, which has shown that more than half of the surveyed parents believe that the Internet brings more benefits than dangers to children, but most parents also asked for advice on how to protect their children online and got that advice mostly from school (Ofcom group, 2019). Also, although children and parents see many benefits to using the Internet, they keep in mind the possible dangers that children may encounter on the Internet and now, unlike five years ago, fewer parents agree that the benefits of the Internet outweigh the dangers their children meet using the Internet.

Most parents find it useful for children to use the Internet, not only because it is a good source for learning and help with homework, but also because it helps children with socialization and research skills, but, on the other hand, they also think that the Internet has negative aspects, and cite pornographic content that children encounter as the most dangerous (Kabakci, Ferhan Odabasi and Coklar, 2008). In one study (Muratbegović and Vujović, 2016), the results that were obtained show the attitude of children on the reasons why their parents most often restrict their access to the Internet. In two thirds of cases, the primary reason for this are school obligations (68\%), while only in one out of four cases (27\%) parents believe that the Internet is dangerous. Many parents find it difficult to keep up with the rapid development of new technologies and are most often unaware of the dangers they bring. Therefore, many children spend hours in front of a computer screen without supervision and instructions on how to behave in the virtual world. By the time children start school - if this role could be taken over by teachers - it could already be too late, so educating parents is immensely important in preventing and combating electronic violence (Ciboci, 2014). Parental control of children on the Internet has positive outcomes when parents are actively involved in the child's use of the Internet, such as proposing and sharing good websites (Sindik, 2012). Restricting or prohibiting a child from using the Internet seems ineffective in directing child Internet usage (Lee and Chae, 2007). Shin and Lwin (2017) state that active mediation is considered the most desirable type of mediation because it is associated with higher digital skills and improves children's understanding of the Internet, and it refers to talking to children about their use of the Internet, sharing online activities and explaining positive and negative sides of the Internet, but also point out that parents who are not informed and do not know much about technology and the Internet often have difficulty talking to children about the same, that is, with active mediation. The more educated parents are, the more active mediation is (Livingstone, Haddon and Görzig, 2012), i.e. more educated parents are more frequent Internet users and more technically competent. Restrictive measures, when it comes to the Internet and television, can often negatively affect a child and his or her use of the Internet, and parents are more restrictive if they consider themselves to be less technologically skilled. On the other hand, the more skilled and technologically educated parents are, the more active mediation there is, i.e. parents talk more to their children about their use of the Internet (Livingstone et al., 2017). 
Tena Velki, Marlies Ivanković BENEFITS AND DANGERS OF THE INTERNET FROM.

\section{BENEFITS OF THE INTERNET}

The internet is a useful tool with many positive aspects such as: quick and easy availability of information, educational resources, sharing experiences with others, job or career advancement, community activism, content creation, motivation to learn, entertainment source, fast and easy communication no matter where we are, children and youth writing skills are improved, creativity is encouraged, problem-solving strategies and information selection are encouraged and many other benefits (Hasebrink, Livingstone and Haddon, 2008; Robotić, 2015). Zagreb Child and Youth Protection Center (2014) emphasized that an additional advantage of the Internet is that it teaches children problem solving and encourages the development of strategies for information selection, exchange of experiences, opinions and information with peers and people of similar interests or problems (sites for fans of famous singers and actors, car lovers or some video games). Pregrad, Tomić Latinac, Mikulić and Šeparović (2010) state that the perception of the advantages of electronic media does not differ with age, but that it differs between mothers and fathers, i.e. fathers more often perceive advantages, while mothers see more dangers their children meet online. At the same time, the results show that the level of education of parents significantly affects their attitude towards electronic media. It has been found that parents who have completed primary school have the weakest perception of the dangers that their children encounter on the Internet, and parents with a college in believe that the Internet helps to improve children's knowledge, skills and abilities.

\section{DANGERS ON THE INTERNET}

The media have an increasing role in our lives, they inform, teach, learn, entertain but also manipulate (Glasovac, 2010). Today's children grow up with the media and they learn in the family about life with the media. Many parents do not even know how to protect their child from online dangers, moreover, they admit that their adolescents know more about technology than they do themselves (Smith, 2007). Furthermore, parents are often unaware of the risks on social networks, specifically the risks on Facebook (Grmuša, Tomulić and Anđelić, 2019), which is supported by the fact that parents often post photos of their children on social networks.

Robotic (2015) states that one of the greatest dangers on the Internet for children are criminals who try to establish personal contact with children and take advantage of their immaturity and naive nature. The results of the first conducted national survey of child and youth safety on the Internet have shown that almost every third child, aged 9 to 17, communicates on the Internet with people they have not met live, and more than half of the children have received inappropriate messages (Buljan-Flander, 2008).

Young people are posting more and more information about themselves on social networks; data that make them vulnerable and accessible to malicious individuals. A lot of information about a young person can be learned from posts on open and fully accessible profiles; where they live, with whom they hang out, how and where they spends their free time, which school and which class they go to, one can even follow the daily routine of movement (Velki, Šolić, Gorjanac and Nenadić, 2017). Young people present information about their family members, and very often about their friends without their consent and knowledge (Matijević, 2014). Research on children's experiences and behaviors on the Internet and on the social network Facebook showed that $34 \%$ of children and young people accept requests for friendship from strangers, while $18 \%$ believe that they might go to meet a stranger they met through the social network (Zagreb Child and Youth Protection Center, 2014). 
THEORETICAL AND PRACTICAL PROBLEMS AND DISCUSSIONS

Over $70 \%$ of parents agree with the statement that there is little talk about dangers on the Internet at school, and only $3 \%$ claim that there is enough talk about it at school (Muratbegović and Vujović, 2016). The more parents monitor their child's use of the Internet, the more negative aspects of children's advertising games are noticed (Evans, 2014). Furthermore, the more negative sides of children's advertising games parents notice, the more they change their attitudes about controlling children when playing the aforementioned games.

Teachers and students who use the Internet more often perceive more positive social aspects of the Internet (Pregrad et al., 2010). Moreover, both parents and teachers have a more pronounced perception of the dangers that the Internet can have on children than the perception of the beneficial aspects of the Internet on children and their upbringing. Parents and teachers do not differ significantly in their perception of the benefits of the Internet. However, in attitudes about the dangers that the Internet can have on children, the data show that teachers have statistically significant and more pronounced attitudes about the existence of such dangers than parents (Pregrad et al., 2010). Kabakci et al. (2008), based on research results, conclude that parents are of the opinion that the Internet is an inevitable technology for both adults and children, but also that they are aware of the positive and negative effects of the Internet that their children encounter.

The aim of this research was to find out what the parents' perception of the dangers of the Internet that their children encounter is, i.e. whether parents who use the Internet frequently consider the Internet to be their children's "safe place" where they can spend some free time with or without parental control or if it is a dangerous place that is not suitable for children. The results of this research can greatly help primary school teachers to gain insight into the way parents think about the potential benefits and dangers of the Internet and as a starting point in designing prevention programs.

\section{Method}

\section{Research aim and hypotheses}

The aim of the research is to examine the parents' perception of the dangers and benefits on the Internet that their children encounter.

In accordance with the previous research and the aim, we set the following hypotheses:

1. Parents who use the Internet more often perceive fewer dangers on the Internet that their children encounter.

2. Parents who use the Internet more often perceive more benefits of electronic media.

3. Parents with a higher level of education perceive more benefits and less dangers during the usage of electronic media by their children.

\section{Research participants}

Ninety-six parents of primary school students participated in the study, of whom the greater percentage were mothers $(N=79,82.3 \%)$ than fathers $(N=17,17.7 \%)$. Most parents range from 30 to 39 years $(N=57,59.4 \%)$, followed by $40-49$ years $(N=35,36.5 \%)$ and $50-59$ years $(N=4.2,4.2 \%)$. Most parents $(69.8 \%)$ stated that they use the Internet for more than one hour a day. 


\section{MeAsURIng instrument}

\section{General data}

The sociodemographic part of the questionnaire was created for research purposes. It consists of a series of questions, namely: gender, age, who completes the questionnaire, parental employment, financial situation of the family, level of education of mother and father and the frequency of the Internet use on the Likert-type scale with 5 degrees (more than 5 hours per day, 1-5 hours a day, a few hours a week, a few hours a month, never).

\section{Scale of attitudes about benefits and dangers of electronic media (Tomić Latinac, Pregrad and Ćosić, 2010)}

The scale of attitudes about benefits and dangers of electronic media consists of twenty questions. Ten questions relate to the danger subscale, and the other ten questions to the electronic media benefits subscale. The scale is of the Likert type, so for each statement answers from 1 to 5 are offered that indicate the degree of agreement with the statements, and the participant should circle for each statement how much he/she agrees with it where number 1 means "I do not agree at all", and number 5 means that the participant fully agrees with the statement. The result is formed as the arithmetic mean of the selected particles.

Given that this is a recent instrument, for which previous use has not shown a fully consistent factor structure, we conducted a factor analysis (principal component analysis, with oblimin rotation) which showed a clear two-factor structure according to the scree test criterion and characteristic root. The first factor refers to the Scale of Perceived Benefits of Electronic Media, which consists of 10 particles that explain $33.44 \%$ of the variance, and has a high internal reliability Cronbach $\alpha=0.87$. The second factor refers to the Scale of Perceived Dangers of Electronic Media, which consists of 10 particles that explain $12.46 \%$ of the variance, and has a high internal Cronbach reliability $\alpha=0.82$.

\section{Data collection process}

The data collection process began with a consent from the principal of the primary school where the research was conducted. After the school approved the research, the questionnaires were distributed to the primary school teachers, who distributed the questionnaires to the students so that they could pass them on to their parents.

In one class, questionnaires were distributed during a parent-teacher meeting. Prior to this, it was explained that the research aims are to examine the opinions about electronic media that children use, and it was emphasized that the research was completely anonymous and voluntary. All parents of students in that class completed the questionnaires in 10 to 15 minutes.

The questionnaires were collected gradually as students brought them to school, and due to the situation with the COVID-19 coronavirus epidemic, slightly fewer questionnaires were collected than expected because the classes took the online form.

\section{RESEARCH RESULTS}

Table 1 shows descriptive statistics of the measured variables (education of parents, frequency of the Internet use, benefits and dangers of electronic media). Data from all participants were collected for all variables used $(\mathrm{N}=96)$. 
The asymmetry index (skewness and kurtosis) did not deviate significantly from the normal distribution because their value did not exceed $+/-2$, so parametric statistics were applied when testing the hypotheses.

Table 1. Descriptive data for measured variables

\begin{tabular}{|l|c|c|c|c|c|c|c|}
\hline & $\mathrm{N}$ & Min & Max & $\mathrm{M}$ & SD & $\begin{array}{c}\text { Asymmetry } \\
\text { index: } \\
\text { Skewness }\end{array}$ & $\begin{array}{c}\text { Asymmetry } \\
\text { index: } \\
\text { Kurtosis }\end{array}$ \\
\hline Education & 96 & 2,00 & 5,00 & 3,714 & 0,781 & 0,359 & $-1,005$ \\
\hline $\begin{array}{l}\text { Frequency of the } \\
\text { Internet use }\end{array}$ & 96 & 2,00 & 5,00 & 3,792 & 0,695 & $-0,272$ & 0,121 \\
\hline $\begin{array}{l}\text { Perceived benefits } \\
\text { of electronic media }\end{array}$ & 96 & 1,60 & 5,00 & 3,601 & 0,630 & $-0,475$ & 0,538 \\
\hline $\begin{array}{l}\text { Perceived dangers } \\
\text { of electronic media }\end{array}$ & 96 & 1,30 & 4,80 & 3,231 & 0,617 & $-0,235$ & 0,476 \\
\hline
\end{tabular}

Given the research goal and hypotheses, Pearson correlation coefficients were calculated (Table 2). According to the first hypothesis, it was found that there is a statistically significant negative correlation between the frequency of the Internet use and perceptions of the dangers of electronic media, therefore, the more often parents use the Internet, the less dangers they think their children face. According to the second hypothesis, a statistically significant positive correlation was confirmed between the frequency of the Internet use and the benefits of electronic media, therefore, parents who use the Internet more often perceive more advantages of electronic media. The third and last hypothesis assumes that parents with a higher level of education perceive more benefits and fewer dangers when using electronic media, but this hypothesis was rejected, i.e. no statistically significant correlation was obtained between these variables.

Table 2. The connection between the frequency of the Internet use and the education of parents with the benefits and dangers of electronic media

\begin{tabular}{|l|c|c|c|c|}
\hline & $\begin{array}{c}\text { Frequency of the } \\
\text { Internet use }\end{array}$ & Education & $\begin{array}{c}\text { Perceived benefits } \\
\text { of electronic media }\end{array}$ & $\begin{array}{c}\text { Perceived dangers } \\
\text { of electronic media }\end{array}$ \\
\hline $\begin{array}{l}\text { Frequency of the } \\
\text { Internet use }\end{array}$ & 1 & $-0,043$ & $0,505^{* *}$ & $-0,227^{*}$ \\
\hline Education & $-0,043$ & 1 & 0,034 & 0,009 \\
\hline
\end{tabular}

$* * p<0,01 ; * p<0,05$

\section{Discussion}

Today, more and more children, as well as parents, use various electronic devices every day. A 2017 survey conducted by the Zagreb Child and Youth Protection Center together with the Brave Phone showed that there is not a single parent who does not use at least one electronic device (television, tablet, mobile phone, computer). At the same time, research has shown that almost $60 \%$ of children use a computer, $45 \%$ use the Internet on their own, and $21 \%$ of parents never check their Internet search history.

The aim of this research was to determine what parents' perception of the benefits and dangers on the Internet that their children encounter when using it is. 
Tena Velki, Marlies Ivankovic BENEFITS AND DANGERS OF THE INTERNET FROM.

Livingstone et al. (2011) state that the more often parents use the Internet, the better their Internet skills are, they can better manage, that is, monitor their children's activity on the Internet, and the more often parents use the Internet, the more often children imitate their parents. In the conducted research, the same was confirmed, i.e. it was established that parents who use the Internet more often perceive less dangers on the Internet that their children encounter. When we are confident in our knowledge and skills, there is a high probability that we will overestimate them at some point, i.e. due to the excessive self-confidence we will not react in accordance with the existing knowledge, believing that potentially dangerous situations cannot happen to us. Research has confirmed that people who show the highest knowledge when it comes to using the Internet also exhibit the most risky behaviour while online (Velki and Romstein, 2019).

It should be emphasized that parents are often unaware of the dangers their children face when using the Internet. Although parents clearly emphasize the potential dangers posed by the Internet, they simultaneously present children's personal data and photos on their own profiles without children's consent (Smahel et al., 2020). Frequent use of the Internet by parents leads to a false sense of security by reducing a parent's perception of the real dangers their children may potentially face. Children learn by model, and by observing the parents who are confident in their knowledge when using the Internet and at the same time publishing various private content (e.g. information about themselves, photos, etc.), they receive the wrong message and become risky Internet users themselves. Moreover, from UNICEF's (2017) report on the state of children in the digital world, we learn that many children and parents are unaware of threats to children's privacy that come, for example, from large-scale data processing, which the Internet has now made possible. Only one in four parents provides programs that monitor their child's activity and block inappropriate content, but almost $20 \%$ of parents do not know what activity monitoring programs are or do not have them, and $12 \%$ of parents do not know about programs that block inappropriate content (Buljan-Flander, 2017). Parents who spend less time on the Internet and know less about it are less present in their children's online lives, while teachers who use the Internet more often perceive various possible dangers on the Internet and are more aware of children's behavior on the Internet than parents (Pregrad et al., 2010). Teachers are more often exposed to websites that students visit than parents and talk more with children about what they do online. Problems created on the Internet between students are often transferred from the virtual to the real world, to the classroom, and become part of the problems that teachers deal with on a daily basis. In addition, teachers assign students various online tasks, create online quizzes, communicate with them through social networks, and thus may encounter similar dangers that children encounter when searching the Internet. That is why it is important that, in addition to parents, teachers are informed about the level of exposure of children on the Internet so that they, along with parents, can help and advise them.

The results of the research show that the parents who use the Internet more often perceive more advantages of the electronic media, which is in line with the research of UNICEF (2017), where the same connection was found for both parents and teachers. The better we get acquainted with some content, the better its benefits can be assessed, and the electronic media practically give us unlimited content. Used properly, the Internet offers great opportunities, from learning to various forms of entertainment in a highly motivating environment tailored to the needs of the individual. It is precisely these flexibilities and almost limitless possibilities for learning and entertainment that make the Internet extremely attractive to both parents and students. By nature, we tend to persist in those activities that give us pleasure and avoid those that cause us discomfort, that is, if we notice benefits in a particular activity, and the time invested is pleasant and useful, we will more often engage in these activities such as using the electronic media. A national survey in the UK (Ofcom group, 2019) found that as many as two thirds of children from Wales are aware of the purpose of websites, applications and 
online games, unlike children from other UK countries, and that children from Wales are the most frequent users of the Internet among all countries in the United Kingdom. Yet parents from Wales show the most concern for their children. This shows that parents' attitudes about the benefits or dangers of the Internet differ from parent to parent, but also in different countries and parts of the world and do not depend solely on the frequency of the Internet use and parenting skills. Students, teachers and parents who spend more time on the Internet emphasize its benefits rather than dangers, but when it comes to children's use of the Internet, parents perceive more usefulness of the Internet than teachers (Pregrad et al., 2010), which again indicates the importance of inclusion of teachers in the online world of children.

Highly educated parents differ from parents with completed primary or secondary school in the perceived usefulness of the Internet for the development of children's knowledge, i.e. parents with a university degree believe that the Internet helps improve children's knowledge, skills and abilities (Pregrad et al., 2010). Contrary to this, Livingstone et al. (2011) state that parents with secondary or higher education are less aware of the dangers their children face. In the conducted research, we did not confirm the connection between the perception of the dangers or advantages of using electronic media and the level of education of parents. Thus, a parent's level of education plays no role in a parent's perception of the dangers or benefits their children encounter online. There are various reasons why the results of such research differ, for example, the different level of education of parents does not mean that it is related to their frequency of the Internet use or their skills in using electronic media. Children of parents with higher education use computers for a longer period of time and more often in different ways, but not other types of media (television, radio, certain television programs), compared to parents with secondary education. Although more educated parents could use a computer more skilfully precisely because a higher level of schooling can make it easier for them to learn about the impact of the media on children, this assumption has not been confirmed (Sindik, 2012). But on the other hand, Livingstone et al. (2012) in their research state that the level of parental education has a significant impact exclusively in different types of active mediation of children, that is, the mediation is based on conversation the more educated the parents are. This is directly related to the fact that more educated parents and more frequent Internet users are more technically competent. Obviously, the level of parental education itself has not proven crucial in relation to their perception of the advantages and disadvantages of the Internet, although potentially the level of parental education could play a mediating role through monitoring and advising children on the proper use of the Internet. Parents with a higher level of education, who are more computer-savvy and competent, can transfer their knowledge and skills to the child through active supervision, thus enabling the child to take advantage of the benefits of the Internet with minimal risks. This mediation hypothesis certainly remains to be tested by future research.

The conducted research has several methodological limitations. The research was conducted on a relatively small number of participants so it is not possible to generalize the results to the entire population of parents. Due to the COVID-19 at the time of the research and certain epidemiological measures due to which children no longer attended classes and came to school, part of the data (questionnaire) was not returned, so the number of participants is smaller than expected. A larger number of questionnaires would certainly show a more realistic picture of the parents' perception of the dangers they encounter with their children online. At the same time, the disadvantage is that only parents participated in the research, i.e. we found out their opinions and attitudes, but we did not find out what the children say about it. Also, the number of male participants is smaller, so it was not possible to examine whether there are significant differences in the perception of fathers and mothers, which could give us additional valuable data. In future research, it would be good to explore how often parents control and set certain rules based on their knowledge of the various dangers their children face online, and also how they discuss potentially inappropriate content that children can find on the Inter- 
Tena Velki, Marlies Ivanković BENEFITS AND DANGERS OF THE INTERNET FROM.

net, i.e. whether and in what way they use active mediation. Furthermore, it would be worthwhile to examine the children as well and find out if they are actually aware of what is hidden behind the screen, and at the same time compare their views with the views of their parents. Undoubtedly a valuable source of data can also be primary school teachers, who should be included in future research.

\section{Practical implication of the obtained results}

Most of the parents who participated in the research use the Internet on a daily basis. Does this mean that they have enough knowledge to teach their children how to use the Internet safely, correspond with friends, play online games, search various sites and so on?

Despite the awareness of the risks that the new media carry, there is a large number of parents who do not control their children and leave them alone with the media and media content (Žic, 2017). When it comes to the mechanisms of protection (of oneself and others) in communication on the social network Facebook, the results showed that parents have theoretical knowledge about the above, but do not apply it in everyday practice (Grmuša et al., 2019). Moreover, research shows that teachers are more aware of the risks that children face online than parents (Pregrad et al., 2010).

Considering teachers as important stakeholders in the upbringing of children, the research conducted, despite the limitations, can be useful to teachers because it gives them an insight into the current position and attitude of parents about the benefits and dangers their children face online. In addition to computer knowledge and skills, teachers also have educational skills, and can adequately design educational and preventive workshops, guide and help parents and children in their further "life on the Internet".

Parents should be the ones to refer their children to good and appropriate websites, and if they face problems, they can always seek help of the school. Instead of outdated penalties or bans on the use of the Internet, parents should take the time to show interest in their child's use of the Internet and instruct and protect them in an appropriate manner. Research has shown that the more often parents use the Internet, the less dangers their children encounter on the Internet, but we should take into account that if parents use the Internet more often then they probably have less time to talk to the child and provide supervision so it is questionable whether they really consider it less dangerous or whether they do not have enough time to notice them. Livingstone et al. (2011) state that parents' awareness of risks and safety on the Internet should be increased and conversation and mutual understanding between the child and parents should be encouraged. In this whole process, active mediation is crucial, i.e. sharing the Internet where the child learns from the parents according to the model of good online behavior and active monitoring of the child's online activities with the correction of inappropriate activities on the Internet. Parents should help the child choose educational and fun games, check the content of the game and whether it is appropriate for the child's developmental stage, not allow the computer to become a nanny and substitute the time the child should spend with parents and play with peers (Glasovac, 2010). It is important to give children support and encourage them to talk to an adult they trust if any online problem arises, and teachers with their expertise and useful advice can be of great help.

\section{CONCLUSION}

Today, more and more adults, but also children, use the Internet, which, in addition to all its advantages, also has many negative aspects. With this research, we wanted to find out what the parents' perception of the benefits and dangers of the Internet that their children 
face is. In accordance with the obtained results, we can conclude that parents who use the Internet more often also perceive more benefits that their children encounter on the Internet and fewer disadvantages and dangers. In relation to the level of education, parents did not show differences in perception of either the benefits or dangers of the Internet.

The results of the research can help teachers by giving them an insight into parents' views of the Internet, taking into account that the level of education of parents does not play an important role in their perception of children's use of the Internet. Unfortunately, knowledge alone has not proven to be a sufficient protective factor when it comes to online risks. By increasing awareness of this issue and insight into the real situation, teachers can educate children, but also parents, or encourage students to use the Internet safely and parents to use available parental protection to make their children's future on the Internet much safer. Children are often not brave enough to complain or talk to their parents about the dangers they face online, so they are more likely to talk to their peers or teachers about it. That is why the relationship between parents and educators is very important in order to protect the child in a responsible and appropriate way, but also to educate them for further search of the Internet and the use of other electronic media.

\section{REFERENCES}

Buljan-Flander, G. (2008). Nasilje preko interneta (Cyberbullying). Zagreb: Poliklinika za zaštitu djece i mladih grada Zagreba.

Buljan-Flander, G. (2017). Screen time: Prvo nacionalno istraživanje Poliklinike o izloženosti predškolske djece svim ekranima. Zagreb: Poliklinika za zaštitu djece grada Zagreba.

Ciboci, L. (2014). Grupe mržnje na društvenim mrežama - novi oblici nasilja među djecom i mladima. In M. Majdak, L. Vejmelka, K. Radat \& A. Vuga (Eds.), Zbornik radova konferencije: Nasilje na internetu među i nad djecom i mladima (pp. 13-27). Zagreb: Društvo za socijalnu podršku.

Evans, N. J. (2014). Pinpointing Persuasion in Children's Advergames: Exploring the Relationship Among Parents' Internet Mediation, Marketplace Knowledge, Attitudes, and the Support for Regulation. Journal of Interactive Advertising, 14(2), 73-85.

Glasovac, Z. (2010). Osnovno o medijima i njihovom mogućem utjecaju na djecu predškolske dobi. Belišće: Dječji vrtić Maslačak. Retrieved 10/5/2020 from https://www.djecjivrtic-ivanic.hr/ documents/za-roditelje/preporuke/Utjecaj_medija.pdf.

Grmuša, T., Tomulić, A. M. \& Anđelić, V. (2019). Zaštita privatnosti djece i maloljetnika na društvenoj mreži Facebook: navike i iskustva roditelja. Communication Management Review, 4(1), 78-97.

Hasebrink, U., Livingstone, S. \& Haddon, L. (2008). Comparing Children's Online Opportunities and Risks Across Europe: Cross-national Comparisons for EU Kids Online. London: EU Kids Online.

Kabakci, I., Ferhan Odabasi, H. \& Coklar, A. (2008). Parents' Views about Internet Use of their Children. International journal of education and information technologies, 4(2), 248-255.

Livingstone, S., Haddon L. \& Görzig, A. (2012). Children, risk and safety on the internet: Research and policy challenges in comparative perspective. Bristol: Policy Press.

Livingstone, S., Haddon, L., Görzig, A. \& Ólafsson, K. (2011). Risks and safety on the internet: the perspective of European children: full findings and policy implications from the EU Kids Online survey of 9-16 year olds and their parents in 25 countries. London: EU Kids Online.

Livingstone, S., Ólafsson, K., Helsper, E.J., Lupiáñez Villanueva, F., Veltri, G. A. \& Folkvord, F. (2017). Maximizing opportunities and minimizing risks for children online: The role of digital skills in emerging strategies of parental mediation. Journal of Communication, 67(1), 82-105.

Lee, S. J. \& Chae, Y.G. (2007). Children's Internet Use in a Family Context: Influence on Family Relationships and Parental Mediation. CyberPsychology \& Behavior, 10(5), 640-644.

Matijević, A. (2014). Nasilje nad i među mladima na Internetu. In Majdak, M., Vejmelka, L., Radat, K., \& Vuga, A. (Eds.), Zbornik radova koferencije: Nasilje na internetu među i nad djecom i mladi$m a$ (pp. 39-51). Zagreb: Društvo za socijalnu podršku. 
Tena Velki, Marlies Ivanković BENEFITS AND DANGERS OF THE INTERNET FROM.

Muratbegović, E. \& Vujović, S. (2016). Ponašanje i navike djece na internetu: stavovi djece, roditelja i nastavnika informatike. Sarajevo: Save the Children in North West Balkans.

Mikić, K. \& Rukavina, A. (2006). Djeca i mediji. Zapis, posebni broj. Retrieved 10/5/2020 from http://www.hfs.hr/hfs/zapis_clanak_detail.asp?sif=1604

Ofcom group (2020). Children and parents: Media use and attitudes report 2019. Retrieved 10/5/2020 from https://www.ofcom.org.uk/_data/assets/pdf_file/0023/190616/childrenmedia-use-attitudes-2019-report.pdf

Poliklinika za zaštitu djece i mladih grada Zagreba (2008). O djeci i internetu. Retrieved 10/5/2020 from https://www.poliklinika-djeca.hr/za-roditelje/izazoviroditeljstva/o-djeci-i-internetu/

Poliklinika za zaštitu djece i mladih grada Zagreba (2014). Istraživanje o iskustvima i ponašanjima djece na Internetu i na društvenoj mreži Facebook. Retrieved 21/5/2020 from https://www. poliklinika-djeca.hr/istrazivanja/istrazivanje-o-iskustvima-i-ponasanjima-djece-na-internetu-ina-drustvenoj-mrezi-facebook-2/

Poliklinika za zaštitu djece i mladih grada Zagreba (2017). Prvo nacionalno istraživanje o predškolskoj djeci pred malim ekranima (rezultati). Retrieved 10/5/2020 from https://www.poliklinikadjeca.hr/istrazivanja/prvo-nacionalno-istrazivanje-o-predskolskoj-djeci-pred-malim-ekranima/

Pregrad, J., Tomić Latinac, M., Mikulić, M. \& Šeparović, N. (2010). Iskustva i stavovi djece, roditelja i učitelja prema elektroničkim medijima. Zagreb: Ured UNICEF-a za Hrvatsku.

Robotić, P. (2015). Zamke virtualnog svijeta: zaštita djece i mladih na internetu i prevencija ovisnosti. Journal of Applied Health Sciences, 1(2), 81-96.

Ružić, N. (2011). Zaštita djece na internetu. Nova prisutnost, 9(1), 155-169.

Shin, W. \& Lwin, M. O. (2017). How does "talking about the internet with others" affect teenagers' experience of online risks? The role of active mediation by parents, peers, and school teachers. New Media \& Society, 19(7), 1109-1126.

Sindik, J. (2012). Kako roditelji percipiraju utjecaj medija na predškolsku djecu? Medijska istraživanja, 18(1), 5-33.

Smahel, D., Machackova, H., Mascheroni, G., Dedkova, L., Staksrud, E., Ólafsson, K., Livingstone, S. \& Hasebrink, I. (2020). EU Kids Online 2020: Survey results from 19 countries. EU Kids Online. Retrieved 10/5/2020 from http://www.Ise.ac.uk/media-and-communications/assets/ documents/research/eu-kids-online/reports/EU-Kids-Online-2020-10Feb2020.pdf

Smith, G. (2007). How to Protect Your Children on the Internet: A Road Map for Parents and Teachers. Westport: Praeger.

Tomić Latinac, M., Pregrad, J. \& Ćosić, I. (2010). Skala stavova o prednostima i opasnostima elektroničkih medija. In J. Pregrad, M. Tomić Latinac, M. Mikulić \& N. Šeparović (Eds.), Iskustva i stavovi djece, roditelja i učitelja prema elektroničkim medijima (pp. 11). Zagreb: Ured UNICEF-a za Hrvatsku.

UNICEF (2017). Stanje djece u svijetu u 2017, Djeca u digitalnom svijetu. Retrieved 10/5/2020 from https://www.unicef.hr/wp-content/uploads/2015/09/Izvjestaj-HR_12-17_web.pdf

Velki, T. \& Romstein, K. (2019). User Risky Behavior and Security Awareness through Lifespan. International journal of electrical and computer engineering systems, 9(2), 9-16. https://doi.org/ 10.32985/ijeces.9.2.2

Velki, T., Šolić, K., Gorjanac, V. \& Nenadić, K. (2017). Empirical study on the risky behavior and security awareness among secondary school pupils - validation and preliminary results. Hrvatska udruga za informacijsku i komunikacijsku tehnologiju, elektroniku i mikroelektroniku - MIPRO proceedings, 1496-1500.

Velki, T. \& Šolić, K. (2019). Izazovi digitalnog svijeta. Osijek: Fakultet za odgojne i obrazovne znanosti Sveučilišta Josipa Jurja Strossmayera u Osijeku.

Young, K. \& Nabuco de Abreu, N. C. (2017). Internet Addiction in Children and Adolescent: Risk Factorts, Assessment, and Treatment. New York: Springer Publishing Company.

Zgrabljić Rotar, N. (2005). Medijska pismenost i civilno društvo. Sarajevo: MediaCentar.

Žic, D. (2017). Medijska pismenost roditelja i njihova percepcija društvenih mreža (Diplomski rad). Odsjek za komunikologiju, Fakultet hrvatskih studija Sveučilišta u Zagrebu. 